\title{
Przestrzenno-czasowa analiza dynamiki udziału energii ze źródel odnawialnych w końcowym zużyciu energii w Unii Europejskiej*
}

\section{Streszczenie}

Rozwój sektora energii odnawialnej jest jednym z priorytetów polskiego rządu - zgodnie z Dyrektywą 2009/28/WE państwa członkowskie UE powinny stopniowo zwiększać udział energii ze źródeł odnawialnych w całkowitym zużyciu energii. Szczegółowe cele polityki energetycznej Polski to wzrost udziału energii ze źródeł odnawialnych w finalnym zużyciu energii do poziomu $15,5 \%$ w 2020 r. (19,13\% dla energii elektrycznej, 17,05\% dla ciepłownictwa i chłodnictwa, 11,36\% dla paliw transportowych).

Głównym celem artykułu jest ocena zróżnicowania krajów ze względu na dynamikę udziału energii ze źródeł odnawialnych w całkowitym zużyciu energii w poszczególnych sektorach. W pracy przedstawiono analizę dynamiki udziału energii ze źródeł odnawialnych w finalnym zużyciu energii elektrycznej, ciepłownictwa i chłodnictwa oraz paliw transportowych. Przeprowadzono analizę zmian w uporządkowaniach krajów ze względu na udział energii ze źródeł odnawialnych w końcowym zużyciu energii z wykorzystaniem współczynnika $\tau$ Kendalla. Celem tej analizy jest sprawdzenie hipotezy mówiącej, że uporządkowanie krajów Unii Europejskiej ze względu na udział energii odnawialnej w ogólnym zużyciu energii nie uległo istotnym zmianom w latach 2005-2013. Przedstawiono także wyniki analizy zależności udziału energii odnawialnej w poszczególnych

* Artykuł powstał w ramach realizacji projektu badawczego dofinansowanego ze środków przyznanych Wydziałowi Zarządzania Uniwersytetu Ekonomicznego w Krakowie w ramach dotacji na utrzymanie potencjału badawczego. 
sektorach. Wyodrębniono grupy państw, które charakteryzują się podobną dynamiką udziału energii odnawialnej w końcowym zużyciu energii w poszczególnych sektorach.

Słowa kluczowe: energia odnawialna, analiza dynamiki, rangowanie, grupowanie.

\section{Wprowadzenie}

Jednym z priorytetów Unii Europejskiej zapisywanym w kolejnych dyrektywach jest rozwój sektora energii odnawialnej. Pierwsza dyrektywa unijna dla tego sektora to Dyrektywa 2001/77/WE' ; jej celem było osiągnięcie 7,5-procentowego udziału energii ze źródeł odnawialnych w bilansie zużycia energii elektrycznej brutto w 2010 r. oraz 5,75-procentowego udziału biopaliw w bilansie zużycia paliw transportowych. Cele te były jednak niewiążące, a zatem niezagrożone karą za ich niespełnienie. Druga dyrektywa (znana potem jako Dyrektywa 2003/30/WE2) weszła w życie dopiero w połowie 2003 r., a więc w 2002 r., na etapie negocjacji akcesyjnych Polski, nie było obowiązku jej wdrożenia. Zgodnie z aktualnie obowiązującą Dyrektywą 2009/28/WE3 państwa członkowskie UE powinny stopniowo zwiększać udział energii ze źródeł odnawialnych w całkowitym zużyciu energii. Za niezrealizowanie celów wyznaczonych na 2020 r. grożą kary finansowe. Pakiet klimatyczno-energetyczny zawiera m.in. dwa cele na 2020 r.:

1) co najmniej $20 \%$ końcowego zużycia energii brutto w UE ma pochodzić z odnawialnych źródeł energii - całkowity cel wspólnotowy na poziomie $20 \%$ przekłada się na indywidualne cele dla poszczególnych państw członkowskich z należytym uwzględnieniem sprawiedliwego i odpowiedniego rozdziału zobowiązań, dostosowanego do zróżnicowanych punktów wyjściowych i potencjałów państw członkowskich, w tym obecnego poziomu wykorzystania energii ze źródeł odnawialnych i struktury koszyka energetycznego;

2) co najmniej $10 \%$ końcowego zużycia paliw transportowych pochodzić ma z odnawialnych źródeł energii - cel ten jest jednakowy dla wszystkich państw członkowskich, ponieważ handel paliwami transportowymi nie przysparza trud-

1 Dyrektywa 2001/77/WE Parlamentu Europejskiego i Rady z dnia 27 września 2001 r. w sprawie wspierania produkcji na rynku wewnętrznym energii elektrycznej wytwarzanej ze źródeł odnawialnych, Dz.Urz. UE L 283, 27.10.2001.

2 Dyrektywa 2003/30/WE Parlamentu Europejskiego i Rady z dnia 8 maja 2003 r. w sprawie wspierania użycia w transporcie biopaliw lub innych paliw odnawialnych, Dz.Urz. UE L 123, 17.05.2003.

3 Dyrektywa Parlamentu Europejskiego i Rady 2009/28/WE z dnia 23 kwietnia 2009 r. w sprawie promowania stosowania energii ze źródeł odnawialnych, Dz.Urz. UE L 140/16, 5.06.2009. 
ności; państwa członkowskie nieposiadające w wystarczającym zakresie odpowiednich zasobów będą mogły łatwo uzyskać biopaliwa w inny sposób.

W celu osiągnięcia obowiązkowych, ostatecznych celów państwa członkowskie powinny opracować krajowe plany działań w zakresie energii odnawialnej zawierające informacje o celach sektorowych. Szczegółowe cele polityki energetycznej Polski ${ }^{4}$ to wzrost udziału energii ze źródeł odnawialnych w finalnym zużyciu energii do poziomu 15,5\% w 2020 r. (19,13\% dla energii elektrycznej, $17,05 \%$ dla ciepłownictwa i chłodnictwa, $11,36 \%$ dla paliw transportowych).

Ocena zróżnicowania krajów ze względu na dynamikę udziału energii ze źródeł odnawialnych w poszczególnych sektorach jest głównym celem niniejszego artykułu. Zostanie w nim przedstawiona analiza dynamiki udziału energii ze źródeł odnawialnych w finalnym zużyciu energii elektrycznej, ciepłownictwa i chłodnictwa oraz paliw transportowych. Z wykorzystaniem współczynnika $\tau$ Kendalla przeprowadzona zostanie analiza zmian w uporządkowaniach krajów ze względu na udział energii ze źródeł odnawialnych w końcowym zużyciu energii. W oparciu o tę część analizy sprawdzona zostanie hipoteza mówiąca, że uporządkowanie krajów Unii Europejskiej ze względu na udział energii odnawialnej w ogólnym zużyciu energii nie ulega istotnym zmianom w latach 2005-2013. Zaprezentowane zostaną także wyniki analizy zależności pomiędzy udziałami energii odnawialnej w poszczególnych sektorach. Za pomocą metody $k$-medoidów wyodrębnione zostaną także grupy państw, które charakteryzują się podobną dynamiką udziału energii odnawialnej w końcowym zużyciu energii w poszczególnych sektorach.

Informacje o możliwościach wykorzystania odnawialnych źródeł energii w poszczególnych państwach prezentuje opracowanie [Zervos, Lins i Tesnière 2011], w którym scharakteryzowano nośniki energii odnawialnej wraz z ich procentowym wykorzystywaniem w poszczególnych sektorach. Praca zawiera także analizę możliwości wykorzystania poszczególnych nośników energii przez poszczególne kraje Unii Europejskiej. Aktualną analizę rynku energii w Unii Europejskiej znaleźć można także w opracowaniu [EU Energy in Figures... 2014].

\section{Udział energii odnawialnej w końcowym zużyciu energii w latach 2005-2013}

Jednym z celów określonych w pakiecie klimatyczno-energetycznym jest to, aby co najmniej $20 \%$ końcowego zużycia energii brutto pochodziło z odnawial-

${ }^{4}$ W dniu 2 grudnia 2011 r. Rada Ministrów przyjęła opracowany przez Ministerstwo Gospodarki dokument pn. Uzupełnienie do Krajowego Planu Działania w zakresie energii ze źródeł odnawialnych. 
Tabela 1. Udział energii odnawialnej w końcowym zużyciu energii w latach 2005-2013 oraz cel na $2020 \mathrm{r}$.

\begin{tabular}{|c|c|c|c|c|c|c|c|c|c|c|c|}
\hline $\begin{array}{c}\text { Wyszczegól- } \\
\text { nienie }\end{array}$ & 2005 & 2006 & 2007 & 2008 & 2009 & 2010 & 2011 & 2012 & 2013 & $\begin{array}{l}\text { Cel na } \\
2020 \mathrm{r} .\end{array}$ & $\mathrm{SRC}^{\mathrm{a}}$ \\
\hline $\mathrm{UE}$ & 8,7 & 9,2 & 10,0 & 10,5 & 11,9 & 12,5 & 12,9 & 14,3 & 15,0 & 20,0 & 0,75 \\
\hline Austria & 23,9 & 25,5 & 27,5 & 28,4 & 30,3 & 30,8 & 30,9 & 32,1 & 32,6 & 34,0 & 0,96 \\
\hline Belgia & 2,3 & 2,7 & 3,4 & 3,8 & 5,2 & 5,7 & 6,1 & 7,4 & 7,9 & 13,0 & 0,61 \\
\hline Bułgaria & 9,4 & 9,6 & 9,2 & 10,5 & 12,2 & 14,1 & 14,3 & 16,0 & 19,0 & 16,0 & 1,19 \\
\hline Chorwacja & 12,8 & 12,8 & 12,1 & 12,1 & 13,1 & 14,3 & 15,4 & 16,8 & 18,0 & 20,0 & 0,90 \\
\hline Cypr & 3,1 & 3,3 & 4,0 & 5,1 & 5,6 & 6,0 & 6,0 & 6,8 & 8,1 & 13,0 & 0,62 \\
\hline Czechy & 6,0 & 6,4 & 7,4 & 7,6 & 8,5 & 9,5 & 9,5 & 11,4 & 12,4 & 13,0 & 0,95 \\
\hline Dania & 15,6 & 15,9 & 17,8 & 18,6 & 20,0 & 22,0 & 23,4 & 25,6 & 27,2 & 30,0 & 0,91 \\
\hline Estonia & 17,5 & 16,1 & 17,1 & 18,9 & 23,0 & 24,6 & 25,5 & 25,8 & 25,6 & 25,0 & 1,02 \\
\hline Finlandia & 28,8 & 30,0 & 29,6 & 31,4 & 31,5 & 32,5 & 32,9 & 34,5 & 36,8 & 38,0 & 0,97 \\
\hline Francja & 9,6 & 9,5 & 10,3 & 11,2 & 12,3 & 12,8 & 11,2 & 13,6 & 14,2 & 23,0 & 0,62 \\
\hline Grecja & 7,0 & 7,2 & 8,2 & 8,0 & 8,5 & 9,8 & 10,9 & 13,4 & 15,0 & 18,0 & 0,83 \\
\hline Hiszpania & 8,4 & 9,2 & 9,7 & 10,8 & 13,0 & 13,8 & 13,2 & 14,3 & 15,4 & 20,0 & 0,77 \\
\hline Holandia & 2,3 & 2,6 & 3,1 & 3,4 & 4,1 & 3,7 & 4,3 & 4,5 & 4,5 & 16,0 & 0,28 \\
\hline Irlandia & 2,9 & 3,1 & 3,6 & 4,1 & 5,1 & 5,6 & 6,6 & 7,3 & 7,8 & 16,0 & 0,49 \\
\hline Litwa & 17,0 & 17,0 & 16,7 & 18,0 & 20,0 & 19,8 & 20,2 & 21,7 & 23,0 & 23,0 & 1,00 \\
\hline Luksemburg & 1,4 & 1,5 & 2,7 & 2,8 & 2,9 & 2,9 & 2,9 & 3,1 & 3,6 & 11,0 & 0,33 \\
\hline Łotwa & 32,3 & 31,1 & 29,6 & 29,8 & 34,3 & 30,4 & 33,5 & 35,8 & 37,1 & 40,0 & 0,93 \\
\hline Malta & 0,2 & 0,2 & 0,2 & 0,2 & 0,2 & 1,0 & 1,4 & 2,7 & 3,8 & 10,0 & 0,38 \\
\hline Niemcy & 6,7 & 7,7 & 9,0 & 8,5 & 9,9 & 10,4 & 11,4 & 12,1 & 12,4 & 18,0 & 0,69 \\
\hline Polska & 6,9 & 6,9 & 6,9 & 7,7 & 8,7 & 9,2 & 10,3 & 10,9 & 11,3 & 16,0 & 0,71 \\
\hline Portugalia & 19,5 & 20,8 & 21,9 & 23,0 & 24,4 & 24,2 & 24,7 & 25,0 & 25,7 & 31,0 & 0,83 \\
\hline Rumunia & 17,6 & 17,1 & 18,3 & 20,5 & 22,7 & 23,4 & 21,4 & 22,8 & 23,9 & 24,0 & 1,00 \\
\hline Słowacja & 5,9 & 6,3 & 7,6 & 7,7 & 9,3 & 9,0 & 10,3 & 10,4 & 9,8 & 14,0 & 0,70 \\
\hline Słowenia & 16,0 & 15,6 & 15,6 & 15,0 & 19,0 & 19,3 & 19,4 & 20,2 & 21,5 & 25,0 & 0,86 \\
\hline Szwecja & 40,5 & 42,6 & 44,1 & 45,2 & 48,2 & 47,2 & 48,9 & 51,1 & 52,1 & 49,0 & 1,06 \\
\hline Węgry & 4,5 & 5,1 & 5,9 & 6,5 & 8,0 & 8,6 & 9,1 & 9,5 & 9,8 & 15,0 & 0,65 \\
\hline $\begin{array}{l}\text { Wielka } \\
\text { Brytania }\end{array}$ & 1,4 & 1,6 & 1,8 & 2,4 & 3,0 & 3,3 & 3,8 & 4,2 & 5,1 & 15,0 & 0,34 \\
\hline Włochy & 5,8 & 6,4 & 6,4 & 7,3 & 9,1 & 10,5 & 12,1 & 15,4 & 16,7 & 17,0 & 0,98 \\
\hline
\end{tabular}

${ }^{a} \mathrm{SRC}$ - stopień realizacji celów.

Uwaga: pogrubioną czcionką wyróżniono wartości, które wskazują na zrealizowanie celu.

Źródło: obliczenia własne. 
nych źródeł energii, przy czym w każdym z krajów Unii Europejskiej udział ten ma być inny. Jak wynika $\mathrm{z}$ analizy danych zawartych w tabeli 1 udział odnawialnych źródeł energii w końcowym zużyciu energii w poszczególnych krajach jest różny 5 .

Cztery kraje: Bułgaria (cel - 16,0\%; w 2013 r. było 19,0\%), Estonia (cel 25,0\%; w 2013 r. było 25,6\%), Litwa (cel - 23,0\%; w 2013 r. było 23,0\%) i Szwecja (cel - 49,0\%; w 2013 r. było 52,1\%), już w 2013 r. zrealizowały swoje zobowiązania wynikające z pakietu klimatyczno-energetycznego. Austria, Finlandia i Łotwa bliskie są osiągnięcia celu, mimo że dla tych państw udział energii odnawialnej, jaki mają osiągnąć w 2020 r., jest bardzo wysoki w stosunku do wartości dla Unii Europejskiej jako całości. Bliskie osiągnięcia celu, choć już nie tak wysoko postawionego, są: Chorwacja, Czechy, Rumunia i Włochy. W 2013 r. najniższy stopień realizacji celu ${ }^{6}$ odnotowano w Holandii, dalekie od osiągnięcia celu zapisanego w Dyrektywie są też: Luksemburg, Malta i Wielka Brytania.

W latach 2005-2013 wzrósł średni udział energii odnawialnej w końcowym zużyciu energii w krajach Unii Europejskiej z 11,6\% do 17,9\% (por. tabela 2). Widoczne jest bardzo duże zróżnicowanie pomiędzy poszczególnymi krajami, które jednak zmniejsza się w badanym okresie (współczynnik zmienności w 2005 r. wynosił 86\%, a w 2013 r. już tylko 64\%). Zaobserwowano niezbyt silną asymetrię prawostronną, co wskazuje na to, że w większości państw udział ten jest niższy niż średnia dla UE.

Na rys. 1 porównano stopień realizacji celów w poszczególnych krajach Unii Europejskiej z przyrostem udziału energii ze źródeł odnawialnych w 2013 r. W większości krajów przyrost ten jest nie większy niż 10\% (por. tabela 3), dotyczy to zarówno krajów, które już w 2013 r. zrealizowały cel (Szwecja i Litwa) lub którym brakuje niewiele do zrealizowania celu (np. Rumunia, Włochy, Austria i Finlandia), jak również krajów, w których stopień realizacji celów jest zdecydowanie niższy (Irlandia). Bułgaria, mimo że już zrealizowała cel na 2020 r., wciąż odnotowuje duży przyrost udziału (niemal 20\%). Podobny przyrost zaobserwowano także w krajach, którym do osiągnięcia celu brakuje jeszcze bardzo dużo (Luksemburg i Wielka Brytania). Zdecydowanie największy przyrost zanotowano na Malcie (ponad 40\%), należy jednak podkreślić, że jest to kraj, któremu do osiągnięcia celu (najniższego w całej Unii Europejskiej) wciąż bardzo dużo brakuje. Tylko na Słowacji i w Estonii w 2013 r. zanotowano spadek udziału OZE w porównaniu z poprzednim rokiem. Przy czym w Estonii cel na

5 Wykorzystano dane Eurostatu, http://ec.europa.eu/eurostat (dostęp: 2.05.2015).

${ }^{6}$ Stopień realizacji celów wyznaczony został jako stosunek udziału energii odnawialnej w 2013 r. do zapisanego w Dyrektywie celu danego państwa na 2020 r. 
Tabela 2. Charakterystyki liczbowe dotyczące udziału energii odnawialnej w końcowym zużyciu energii w latach 2005-2013 w krajach Unii Europejskiej

\begin{tabular}{|l|r|r|r|r|r|r|r|r|r|}
\hline \multicolumn{1}{|c|}{ Statystyki } & \multicolumn{1}{c|}{2005} & 2006 & 2007 & 2008 & 2009 & 2010 & 2011 & 2012 & 2013 \\
\hline Średnia & 11,6 & 11,9 & 12,5 & 13,2 & 14,7 & 15,2 & 15,7 & 16,9 & 17,9 \\
\hline Mediana & 7,7 & 8,5 & 9,1 & 9,5 & 11,1 & 11,7 & 11,8 & 14,0 & 15,2 \\
\hline Minimum & 0,2 & 0,2 & 0,2 & 0,2 & 0,2 & 1 & 1,4 & 2,7 & 3,6 \\
\hline Maksimum & 40,5 & 42,6 & 44,1 & 45,2 & 48,2 & 47,2 & 48,9 & 51,1 & 52,1 \\
\hline $\begin{array}{l}\text { Odchylenie stan- } \\
\text { dardowe }\end{array}$ & 10,01 & 10,18 & 10,19 & 10,46 & 11,11 & 10,77 & 10,99 & 11,29 & 11,50 \\
\hline $\begin{array}{l}\text { Współczynnik } \\
\text { zmienności }\end{array}$ & 0,86 & 0,85 & 0,82 & 0,79 & 0,75 & 0,71 & 0,70 & 0,67 & 0,64 \\
\hline Asymetria & 1,25 & 1,35 & 1,37 & 1,32 & 1,22 & 1,10 & 1,18 & 1,16 & 1,11 \\
\hline
\end{tabular}

Źródło: obliczenia własne.

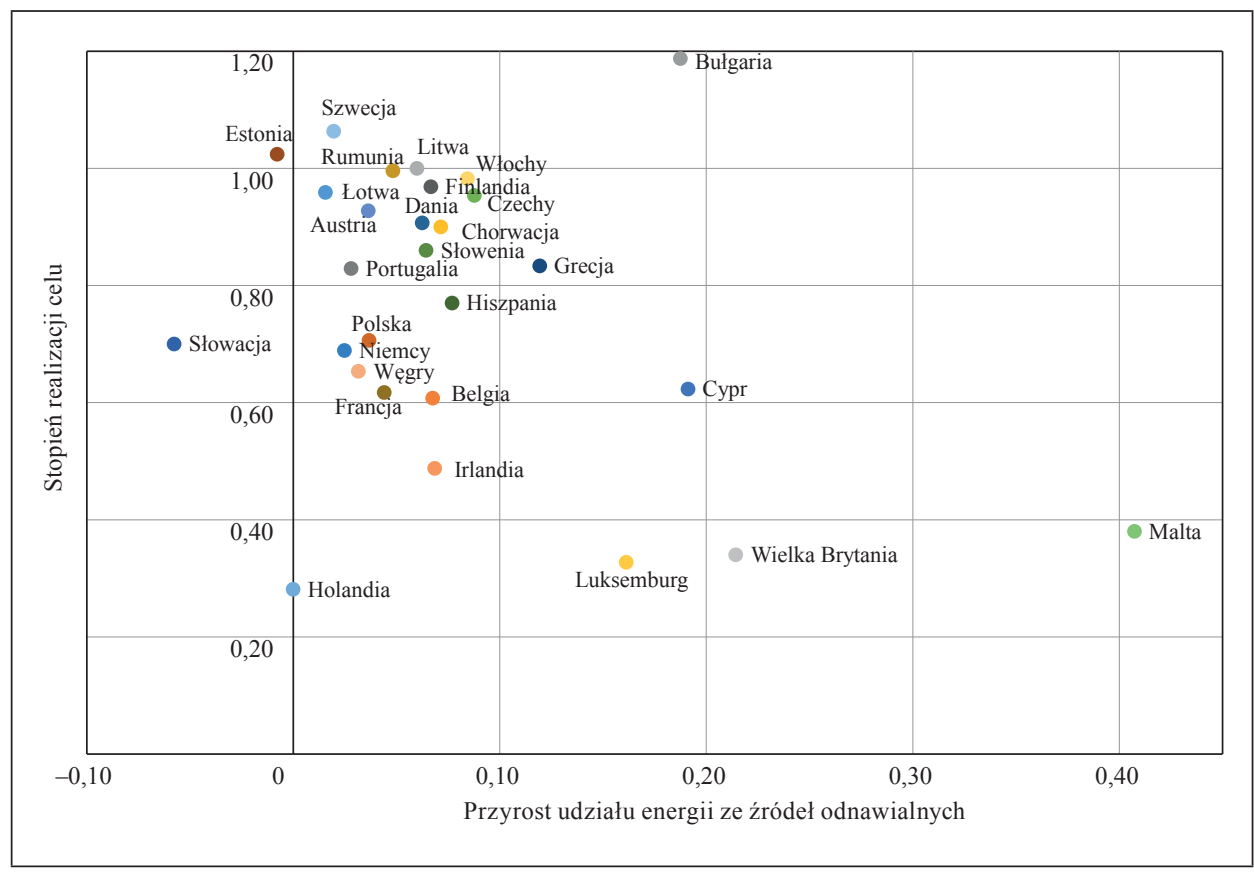

Rys. 1. Przyrost udziału energii ze źródeł odnawialnych w końcowym zużyciu energii ogółem oraz stopień realizacji celów w krajach Unii Europejskiej w 2013 r. Źródło: opracowanie własne. 
Tabela 3. Dynamika udziału energii odnawialnej w końcowym zużyciu energii w latach 2006-2013 a oraz średniookresowe tempo zmian (w \%)

\begin{tabular}{|c|c|c|c|c|c|c|c|c|c|c|}
\hline $\begin{array}{c}\text { Wyszczegól- } \\
\text { nienie }\end{array}$ & 2006 & 2007 & 2008 & 2009 & 2010 & 2011 & 2012 & 2013 & $\begin{array}{l}\text { Średnio- } \\
\text { okresowe } \\
\text { tempo } \\
\text { zmian }\end{array}$ & $\begin{array}{c}\text { Czy cel } \\
\text { zostanie } \\
\text { zrealizo- } \\
\text { wany? }\end{array}$ \\
\hline UE & 6 & 9 & 5 & 13 & 5 & 3 & 11 & 5 & 7 & tak \\
\hline Austria & 7 & 8 & 3 & 7 & 2 & 0 & 4 & 2 & 4 & tak \\
\hline Belgia & 17 & 26 & 12 & 37 & 10 & 7 & 21 & 7 & 17 & tak \\
\hline Bułgaria & 2 & -4 & 14 & 16 & 16 & 1 & 12 & 19 & 9 & tak \\
\hline Chorwacja & 0 & -5 & 0 & 8 & 9 & 8 & 9 & 7 & 4 & tak \\
\hline Cypr & 6 & 21 & 28 & 10 & 7 & 0 & 13 & 19 & 13 & tak \\
\hline Czechy & 7 & 16 & 3 & 12 & 12 & 0 & 20 & 9 & 9 & tak \\
\hline Dania & 2 & 12 & 4 & 8 & 10 & 6 & 9 & 6 & 7 & tak \\
\hline Estonia & -8 & 6 & 11 & 22 & 7 & 4 & 1 & -1 & 5 & tak \\
\hline Finlandia & 4 & -1 & 6 & 0 & 3 & 1 & 5 & 7 & 3 & tak \\
\hline Francja & -1 & 8 & 9 & 10 & 4 & -13 & 21 & 4 & 5 & nie \\
\hline Grecja & 3 & 14 & -2 & 6 & 15 & 11 & 23 & 12 & 10 & tak \\
\hline Hiszpania & 10 & 5 & 11 & 20 & 6 & -4 & 8 & 8 & 8 & tak \\
\hline Holandia & 13 & 19 & 10 & 21 & -10 & 16 & 5 & 0 & 9 & nie \\
\hline Irlandia & 7 & 16 & 14 & 24 & 10 & 18 & 11 & 7 & 13 & tak \\
\hline Litwa & 0 & -2 & 8 & 11 & -1 & 2 & 7 & 6 & 4 & tak \\
\hline Luksemburg & 7 & 80 & 4 & 4 & 0 & 0 & 7 & 16 & 13 & nie \\
\hline łotwa & -4 & -5 & 1 & 15 & -11 & 10 & 7 & 4 & 2 & tak \\
\hline Malta & 0 & 0 & 0 & 0 & 400 & 40 & 93 & 41 & 44 & tak \\
\hline Niemcy & 15 & 17 & -6 & 16 & 5 & 10 & 6 & 2 & 8 & tak \\
\hline Polska & 0 & 0 & 12 & 13 & 6 & 12 & 6 & 4 & 6 & tak \\
\hline Portugalia & 7 & 5 & 5 & 6 & -1 & 2 & 1 & 3 & 4 & tak \\
\hline Rumunia & -3 & 7 & 12 & 11 & 3 & -9 & 7 & 5 & 4 & tak \\
\hline Słowacja & 7 & 21 & 1 & 21 & -3 & 14 & 1 & -6 & 7 & tak \\
\hline Słowenia & -3 & 0 & -4 & 27 & 2 & 1 & 4 & 6 & 4 & tak \\
\hline Szwecja & 5 & 4 & 2 & 7 & -2 & 4 & 4 & 2 & 3 & tak \\
\hline Węgry & 13 & 16 & 10 & 23 & 8 & 6 & 4 & 3 & 10 & tak \\
\hline $\begin{array}{l}\text { Wielka } \\
\text { Brytania }\end{array}$ & 14 & 13 & 33 & 25 & 10 & 15 & 11 & 21 & 18 & tak \\
\hline Włochy & 10 & 0 & 14 & 25 & 15 & 15 & 27 & 8 & 14 & tak \\
\hline
\end{tabular}

${ }^{a}$ Dynamika liczona w stosunku do roku poprzedniego.

Źródło: obliczenia własne. 
2020 r. został już zrealizowany, a Słowacji do realizacji celu wciąż jeszcze dużo brakuje.

Analiza dynamiki wskazuje, że udział energii odnawialnej w końcowym zużyciu energii rośnie we wszystkich krajach. Największe średniookresowe tempo zmian zaobserwować można na Malcie, tutaj udział energii odnawialnej rośnie średnio o 44,5\% z roku na rok. Do krajów o wysokiej dynamice należą także: Wielka Brytania, Belgia, Włochy, Irlandia, Cypr, Luksemburg, Węgry i Grecja. Zaznaczyć jednak należy, że są to przeważnie kraje, w których w 2013 r. udział energii ze źródeł odnawialnych był stosunkowo niski (niższy niż średnia dla UE). Najniższą dynamiką charakteryzują się kraje, w których udział energii ze źródeł odnawialnych jest zdecydowanie wyższy niż średnia dla UE. Przyjmując dotychczasowe tempo zmian, stwierdzić można, że większość krajów osiągnie cel wyznaczony na 2020 r. Tylko Francja, Luksemburg i Holandia nie osiągną celów, jeśli udział energii ze źródeł odnawialnych nie będzie rósł w większym tempie.

W celu porównania uporządkowań krajów ze względu na udział energii ze źródeł odnawialnych w końcowym zużyciu energii w kolejnych latach wyznaczono współczynnik $\tau$ Kendalla (por. [Kendall 1955, s. 19]). W pracy wykorzystany został współczynnik korelacji $\tau$ Kendalla postaci:

$$
\tau_{l h}=\frac{\sum_{i=2}^{16} \sum_{k=1}^{i-1} a_{i k l} b_{i k h}}{\left[\sum_{i=2}^{16} \sum_{k=1}^{i-1} a_{i k l}^{2} \sum_{i=2}^{16} \sum_{k=1}^{i-1} b_{i k h}^{2}\right]^{\frac{1}{2}}},
$$

gdzie:

$i, k=1, \ldots, n-$ numer obiektu (kraju),

$l, h$ - numer zmiennej,

z podstawieniem [Walesiak 2011, s. 37]:

$$
a_{i k l}\left(b_{i k h}\right)=\left\{\begin{array}{cccc}
1, & \text { gdy } & x_{i l}>x_{k l} & \left(x_{i h}>x_{k h}\right), \\
0, & \text { gdy } & x_{i l}=x_{k l} & \left(x_{i h}=x_{k h}\right), \\
-1, & \text { gdy } & x_{i l}<x_{k l} & \left(x_{i h}<x_{k h}\right),
\end{array}\right.
$$

gdzie:

$x_{i l}, x_{k l}-i$-ta $(k$-ta) obserwacja dla $l$-tej zmiennej.

Współczynnik $\tau$ Kendalla przyjmuje wartości z przedziału $[-1,1]$. Wartość 1 oznacza pełną zgodność uporządkowań, zaś wartość -1 pełną ich przeciwstawność. 
Tabela 4. Wartości współczynnika $\tau$ Kendalla

\begin{tabular}{|c|c|c|c|c|c|c|c|c|}
\hline Rok & 2006 & 2007 & 2008 & 2009 & 2010 & 2011 & 2012 & 2013 \\
\hline 2005 & 0,96 & 0,95 & 0,96 & 0,92 & 0,91 & 0,90 & 0,89 & 0,88 \\
\hline 2006 & & 0,94 & 0,95 & 0,93 & 0,94 & 0,92 & 0,91 & 0,90 \\
\hline 2007 & & & 0,99 & 0,94 & 0,91 & 0,90 & 0,88 & 0,88 \\
\hline 2008 & & & & 0,94 & 0,92 & 0,91 & 0,88 & 0,87 \\
\hline 2009 & & & & & 0,93 & 0,93 & 0,91 & 0,89 \\
\hline 2010 & & & & & & 0,95 & 0,95 & 0,93 \\
\hline 2011 & & & & & & & 0,96 & 0,92 \\
\hline 2012 & & & & & & & & 0,95 \\
\hline
\end{tabular}

Źródło: obliczenia własne.

Jak wynika z analizy tabeli 4, uporządkowania w kolejnych latach są niemal identyczne. Mimo znacznych różnic dotyczących tempa przyrostu udziału energii ze źródeł odnawialnych w poszczególnych państwach uporządkowania krajów ze względu na udział energii odnawialnej w końcowym zużyciu energii nie ulegają zmianom w kolejnych latach.

\section{Udział energii odnawialnej w końcowym zużyciu energii w poszczególnych sektorach}

Handel paliwami transportowymi nie przysparza trudności, stąd też UE przyjęła dla wszystkich krajów członkowskich ten sam cel na poziomie $10 \%$. W 2013 r. tylko Szwecja, z udziałem 16,7\%, osiągnęła zamierzony poziom (por. rys. 2).

Wysoki współczynnik zmienności w całym badanym okresie (128\% w $2005 \mathrm{r}$. i aż 149\% w 2013 r.) potwierdza bardzo duże zróżnicowanie krajów ze względu na udział energii odnawialnej w końcowym zużyciu paliw transportowych. Obserwuje się także znaczny wzrost średniego udziału dla Unii Europejskiej (por. tabela 5).

W dziedzinie energii elektrycznej wszystkie kraje członkowskie zanotowały wzrost udziału energii odnawialnej (por. rys. 3). Największy wzrost wystąpił w Estonii i Belgii (w 2013 r. wzrost odpowiednio o ponad 1000\% i 400\% w stosunku do 2005 r.).

Zauważyć można także znaczny wzrost średniego udziału energii odnawialnej w końcowym zużyciu energii elektrycznej dla UE (por. tabela 6). Maleje zróżnicowanie pomiędzy krajami (współczynnik zmienności obniżył się z 99\% 


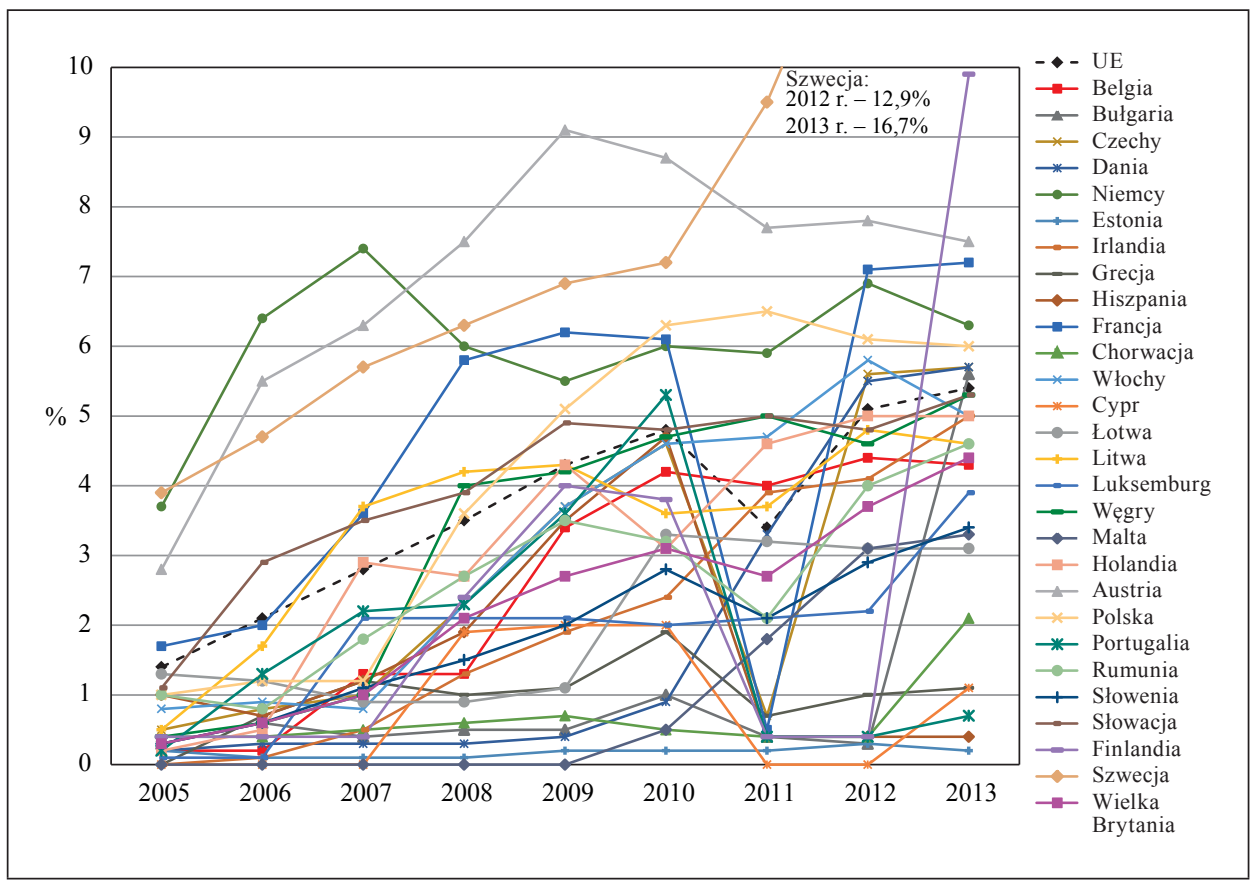

Rys. 2. Udział energii ze źródeł odnawialnych w końcowym zużyciu paliw transportowych w latach 2005-2013

Źródło: opracowanie własne.

Tabela 5. Charakterystyki liczbowe dla udziału energii odnawialnej w końcowym zużyciu paliw transportowych w latach 2005-2013

\begin{tabular}{|l|r|r|r|r|r|r|r|r|r|}
\hline \multicolumn{1}{|c|}{ Statystyki } & 2005 & 2006 & 2007 & 2008 & 2009 & 2010 & 2011 & 2012 & 2013 \\
\hline Średnia & 0,8 & 1,3 & 1,9 & 2,6 & 3,2 & 3,6 & 2,9 & 3,8 & 4,8 \\
\hline Mediana & 0,4 & 0,7 & 1,2 & 2,2 & 3,5 & 3,5 & 2,4 & 4,1 & 4,8 \\
\hline $\begin{array}{l}\text { Współczynnik } \\
\text { zmienności }\end{array}$ & 1,28 & 0,78 & 0,97 & 1,32 & 1,50 & 1,73 & 1,18 & 1,32 & 1,49 \\
\hline Asymetria & 2,04 & 2,14 & 1,58 & 0,97 & 0,59 & 0,32 & 0,82 & 0,87 & 1,73 \\
\hline
\end{tabular}

Źródło: obliczenia własne.

do 68\%), równocześnie zaobserwować można zmniejszenie się asymetrii prawostronnej (współczynnik asymetrii obniżył się z 1,29 do 0,86).

Jak wynika z analizy rys. 4, największy wzrost udziału energii odnawialnej w końcowym zużyciu energii w ciepłownictwie i chłodnictwie zanotowano na Malcie (ponad 10-krotny) oraz we Włoszech (niemal 4-krotny). 


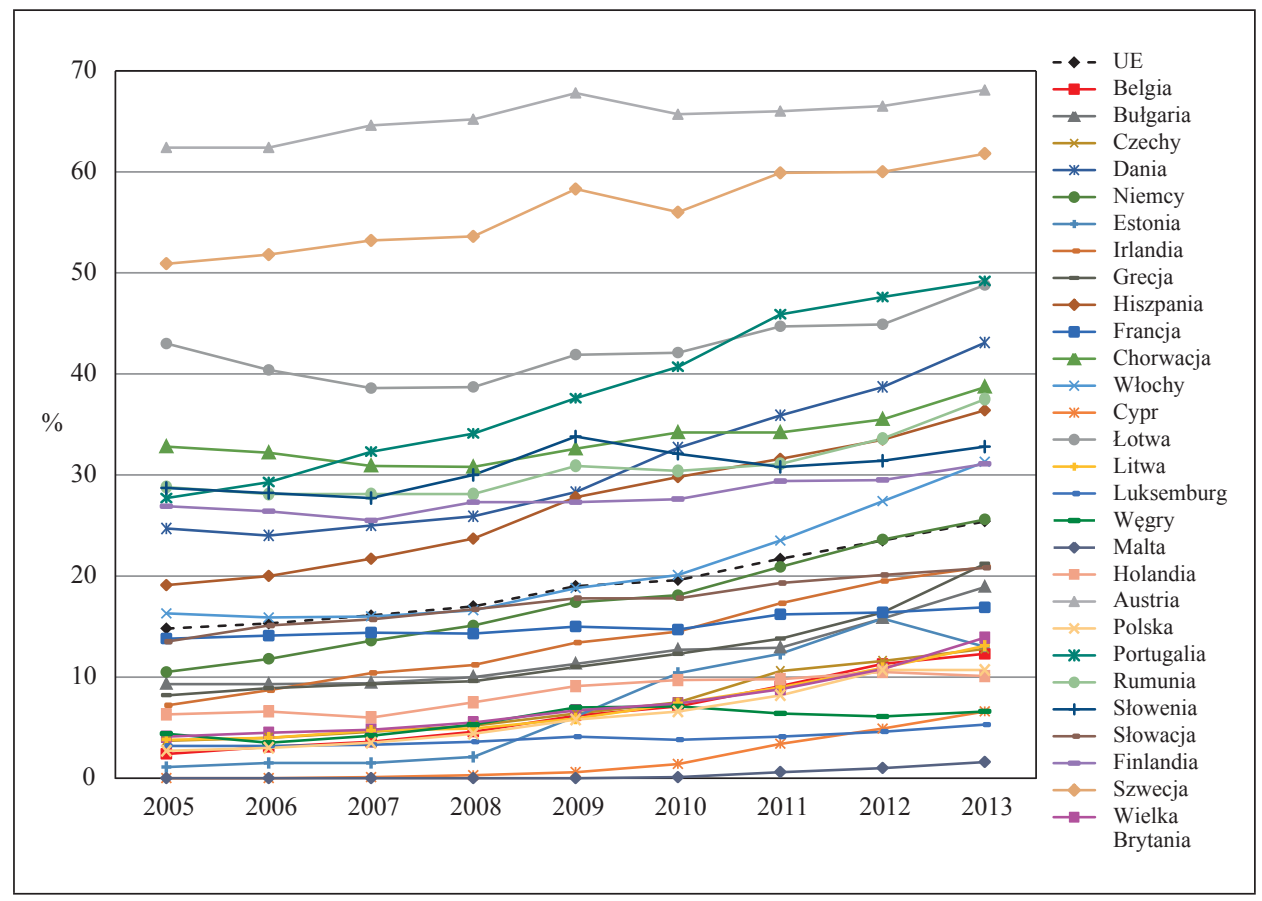

Rys. 3. Udział energii ze źródeł odnawialnych w końcowym zużyciu energii elektrycznej w latach 2005-2013

Źródło: opracowanie własne.

Tabela 6. Charakterystyki liczbowe dla udziału energii odnawialnej w końcowym zużyciu energii elektrycznej w latach 2005-2013 w krajach Unii Europejskiej

\begin{tabular}{|l|c|c|c|c|c|c|c|c|c|}
\hline \multicolumn{1}{|c|}{ Statystyki } & 2005 & 2006 & 2007 & 2008 & 2009 & 2010 & 2011 & 2012 & 2013 \\
\hline Średnia & 16,3 & 16,4 & 16,9 & 17,7 & 19,6 & 20,4 & 22,0 & 23,5 & 25,3 \\
\hline Mediana & 9,9 & 10,6 & 12,0 & 12,8 & 14,2 & 14,6 & 16,8 & 18,0 & 20,9 \\
\hline $\begin{array}{l}\text { Współczynnik } \\
\text { zmienności }\end{array}$ & 0,99 & 0,96 & 0,95 & 0,91 & 0,86 & 0,80 & 0,76 & 0,70 & 0,68 \\
\hline Asymetria & 1,29 & 1,30 & 1,36 & 1,31 & 1,26 & 1,12 & 1,08 & 0,98 & 0,86 \\
\hline
\end{tabular}

Źródło: obliczenia własne.

W sektorze ciepłownictwa i chłodnictwa wzrost udziału energii odnawialnej dotyczy nie tylko UE jako całości (wzrost średniej z 15,6\% w 2005 r. do 23,8\% w 2013 r.), ale także wszystkich poszczególnych państw członkowskich (zob. tabela 7). Maleje zróżnicowanie (spadek współczynnika zmienności w kolejnych 


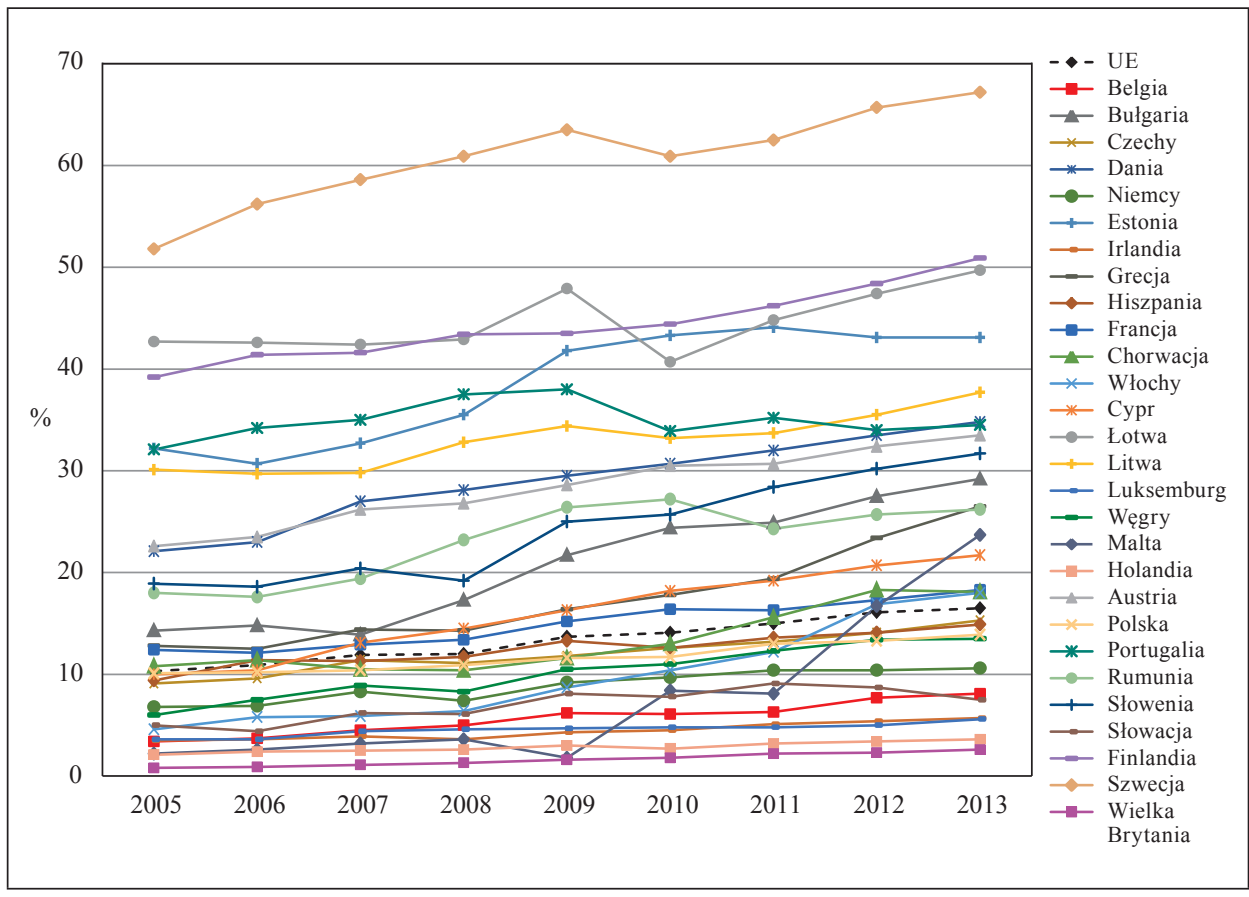

Rys. 4. Udział energii ze źródeł odnawialnych w końcowym zużyciu energii w ciepłownictwie i chłodnictwie w latach 2005-2013

Źródło: opracowanie własne.

Tabela 7. Charakterystyki liczbowe dla udziału energii odnawialnej w końcowym zużyciu energii w ciepłownictwie i chłodnictwie w latach 2005-2013 w krajach Unii Europejskiej

\begin{tabular}{|l|c|c|c|c|c|c|c|c|c|}
\hline \multicolumn{1}{|c|}{ Statystyki } & 2005 & 2006 & 2007 & 2008 & 2009 & 2010 & 2011 & 2012 & 2013 \\
\hline Średnia & 15,6 & 16,1 & 17,1 & 18,0 & 19,8 & 20,2 & 21,1 & 22,7 & 23,8 \\
\hline Mediana & 10,5 & 11,4 & 12,2 & 12,6 & 14,3 & 14,7 & 16,0 & 17,8 & 20,0 \\
\hline $\begin{array}{l}\text { Współczynnik } \\
\text { zmienności }\end{array}$ & 0,86 & 0,86 & 0,83 & 0,83 & 0,79 & 0,73 & 0,71 & 0,67 & 0,66 \\
\hline Asymetria & 1,16 & 1,28 & 1,24 & 1,18 & 1,05 & 0,96 & 0,97 & 0,94 & 0,86 \\
\hline
\end{tabular}

Źródło: obliczenia własne. 
latach) przy jednoczesnym zmniejszaniu się asymetrii (zmniejsza się wartość współczynnika asymetrii).

Udział energii odnawialnej w końcowym zużyciu paliw transportowych podlegał w badanym okresie największym zmianom w poszczególnych krajach. Prawdopodobnie jest to związane $\mathrm{z}$ łatwym pozyskaniem biopaliw.

Szczegółowe cele polityki energetycznej Polski zawarte w dokumencie pn. Uzupełnienie do Krajowego Planu Działania w zakresie energii ze źródeł odnawialnych, opracowanym przez Ministerstwo Gospodarki, a przyjętym przez Radę Ministrów 2 grudnia 2011 r., to wzrost udziału energii ze źródeł odnawialnych w finalnym zużyciu energii do poziomu $15,5 \%$ w 2020 r. (19,13\% dla energii elektrycznej, $17,05 \%$ dla ciepłownictwa i chłodnictwa, $11,36 \%$ dla paliw transportowych).

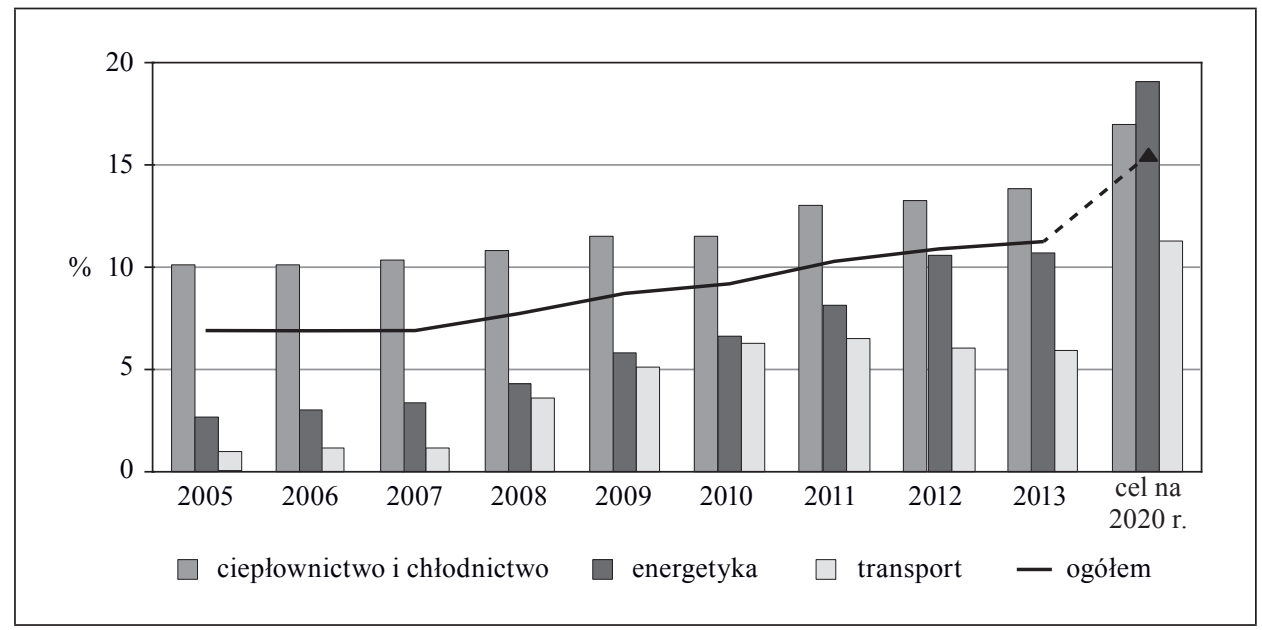

Rys. 5. Udział energii odnawialnej w końcowym zużyciu energii w Polsce w latach 2005-2013 oraz cel na $2020 \mathrm{r}$.

Źródło: opracowanie własne.

Największy wzrost udziału energii odnawialnej w Polsce zanotowano w transporcie (w 2013 r. udział ten stanowił 615\% wartości z 2005 r.), nieco niższy w energetyce (w stosunku do 2005 r. udział ten wzrósł 4-krotnie), a najniższy w ciepłownictwie i chłodnictwie (w 2013 r. wzrost o 37\% w stosunku do 2005 r.). W przypadku wszystkich sektorów zachowanie dotychczasowego średniookresowego tempa zmian pozwoli osiągnąć zamierzone na 2020 r. cele. 


\section{Analiza zależności oraz struktura wykorzystania energii odnawialnej w poszczególnych sektorach}

Analizując zależności pomiędzy wartościami udziału energii odnawialnej w poszczególnych sektorach, zauważyć można bardzo silną dodatnią zależność pomiędzy udziałem energii odnawialnej w końcowym zużyciu energii ogółem a udziałem energii odnawialnej w ciepłownictwie i chłodnictwie (zob. tabela 8). Udział energii odnawialnej w końcowym zużyciu energii ogółem jest także silnie dodatnio skorelowany z udziałem energii odnawialnej w końcowym zużyciu energii elektrycznej. Jedynie w przypadku udziału energii odnawialnej w końcowym zużyciu paliw transportowych zależność ta jest zdecydowanie słabsza.

Tabela 8. Współczynnik korelacji liniowej dla udziału energii odnawialnej w końcowym zużyciu energii ogółem w poszczególnych sektorach w latach 2006-2013

\begin{tabular}{|l|c|c|c|c|c|c|c|c|}
\hline \multicolumn{1}{|c|}{ Sektor } & 2006 & 2007 & 2008 & 2009 & 2010 & 2011 & 2012 & 2013 \\
\hline Transport & $\mathbf{0 , 4 9}$ & $\mathbf{0 , 4 1}$ & 0,35 & 0,33 & 0,30 & 0,32 & 0,27 & 0,29 \\
\hline Energia elektryczna & $\mathbf{0 , 8 0}$ & $\mathbf{0 , 8 1}$ & $\mathbf{0 , 8 2}$ & $\mathbf{0 , 8 0}$ & $\mathbf{0 , 8 1}$ & $\mathbf{0 , 8 1}$ & $\mathbf{0 , 8 2}$ & $\mathbf{0 , 8 2}$ \\
\hline $\begin{array}{l}\text { Ciepłownictwo i chłod- } \\
\text { nictwo }\end{array}$ & $\mathbf{0 , 9 6}$ & $\mathbf{0 , 9 6}$ & $\mathbf{0 , 9 5}$ & $\mathbf{0 , 9 5}$ & $\mathbf{0 , 9 5}$ & $\mathbf{0 , 9 5}$ & $\mathbf{0 , 9 5}$ & $\mathbf{0 , 9 4}$ \\
\hline
\end{tabular}

Uwaga: pogrubioną czcionką wyróżniono wartości istotne statycznie na poziomie $\alpha=0,05$.

Źródło: obliczenia własne.

Nieco inne wyniki dała analiza zależności pomiędzy przyrostami udziału energii odnawialnej w poszczególnych sektorach (zob. tabela 9). Szczególnie w ostatnim okresie badania, tj. w 2013 r., zaobserwowano umiarkowaną zależność dodatnią pomiędzy przyrostem udziału energii odnawialnej w końcowym zużyciu energii ogółem a przyrostem udziału energii odnawialnej we wszystkich sektorach.

Na podstawie danych dotyczących przyrostów udziału energii odnawialnej w końcowym zużyciu energii w poszczególnych sektorach przeprowadzono grupowanie państw Unii Europejskiej w odniesieniu do poszczególnych lat. Zmienne poddane zostały normalizacji z wykorzystaniem przekształcenia ilorazowego z parametrami stałymi w czasie. Grupowaniu podlegało 212 obiekto-okresów ${ }^{7}$, dla których zmiennymi były proste indeksy łańcuchowe udziału

7 Z analizy wykluczono obiekto-okresy, dla których nie dało się wyznaczyć indeksów, ponieważ w poprzednim roku udział energii ze źródeł odnawialnych wynosił zero. Wykluczono takie obiekty, jak: Irlandia 2006, Grecja 2006, Cypr 2006-2008 oraz 2012-2013 i Malta 2006-2010. 
Tabela 9. Współczynnik korelacji liniowej dla przyrostów udziału energii odnawialnej w końcowym zużyciu energii ogółem w poszczególnych sektorach w latach 2006-2013

\begin{tabular}{|l|c|c|c|c|c|c|c|c|}
\hline \multicolumn{1}{|c|}{ Sektor } & 2006 & 2007 & 2008 & 2009 & 2010 & 2011 & 2012 & 2013 \\
\hline Transport & $\mathbf{0 , 4 9}$ & 0,32 & $\mathbf{0 , 3 9}$ & $-0,08$ & $-0,26$ & $\mathbf{0 , 5 4}$ & $\mathbf{0 , 4 8}$ & $\mathbf{0 , 5 7}$ \\
\hline Energia elektryczna & $\mathbf{0 , 4 4}$ & $\mathbf{0 , 6 7}$ & $-0,12$ & $\mathbf{0 , 7 9}$ & $\mathbf{0 , 4 0}$ & 0,34 & 0,14 & $\mathbf{0 , 6 3}$ \\
\hline $\begin{array}{l}\text { Ciepłownictwo i chłod- } \\
\text { nictwo }\end{array}$ & $\mathbf{0 , 8 0}$ & $\mathbf{0 , 7 8}$ & $\mathbf{0 , 8 5}$ & $\mathbf{0 , 8 7}$ & $\mathbf{0 , 7 8}$ & 0,25 & $\mathbf{0 , 3 9}$ & $\mathbf{0 , 4 9}$ \\
\hline
\end{tabular}

Uwaga: pogrubioną czcionką wyróżniono wartości istotne statycznie na poziomie $\alpha=0,05$.

Źródło: obliczenia własne.

energii ze źródeł odnawialnych w poszczególnych sektorach dotyczące konkretnego kraju w danym roku. Grupowanie przeprowadzono ${ }^{8}$ metodą $k$-medoidów ${ }^{9}$ z wykorzystaniem odległości Euklidesa ${ }^{10}$. Liczbę grup równą 4 ustalono, analizując wartości współczynnika sylwetkowego ${ }^{11}$.

W pierwszej grupie znalazły się takie obiekto-okresy, jak: Luksemburg 2007, Francja 2012, Bułgaria 2013 i Finlandia 2013. Charakteryzowały się one największym przyrostem udziału energii odnawialnej w zużyciu paliw transportowych (średni przyrost udziału wyniósł prawie $2000 \%$ ), zaś w pozostałych sektorach przyrost ten był bardzo niski. Najniższą średnią przyrostu udziału energii odnawialnej zaobserwowano w końcowym zużyciu energii elektrycznej - tylko 7,4\%.

Drugą grupę stworzyło sześć obiekto-okresów: Estonia 2009, Cypr 2009, Cypr 2010, Cypr 2011, Malta 2011 i Malta 2012. Charakteryzowały się one największym przyrostem udziału energii odnawialnej w zużyciu energii elektrycznej (średnio o prawie $200 \%$ ) oraz w zużyciu energii w ciepłownictwie i chłodnictwie (średnio przyrost udziału wyniósł 25\%). Była to równocześnie grupa, która charakteryzowała się stosunkowo niskim, bo średnio tylko 56-procentowym, przyrostem udziału energii odnawialnej w zużyciu paliw transportowych.

Dziewięć obiekto-okresów: Portugalia 2006, Belgia 2007, Irlandia 2007, Holandia 2007, Węgry 2008, Finlandia 2008, Dania 2011, Czechy 2012 i Chor-

${ }^{8}$ Obliczenie wykonano $\mathrm{z}$ wykorzystaniem funkcji pam pakietu clusterSim programu $\mathrm{R}$ [R: A Language... 2015].

9 Zdecydowano się na metodę $k$-medoidów ze względu na występowanie obserwacji odstających. Szczegółowy algorytm metody $k$-medoidów znaleźć można w pracy [Kaufmann i Rousseeuw 1990].

${ }^{10}$ Wykorzystano odległość euklidesową jako najczęściej wykorzystywaną odległość w przypadku danych mierzonych na skali przedziałowej i ilorazowej.

11 Współczynnik sylwetkowy (indeks silhouette) zaprezentowany został w pracy [Kaufman i Rousseeuw 1990]. Wybiera się liczbę skupień, dla której wartość współczynnika była największa. 
wacja 2013, utworzyło grupę trzecią, charakteryzującą się najniższym średnim przyrostem udziału energii odnawialnej w końcowym zużyciu energii w ciepłownictwie i chłodnictwie $(5,4 \%)$, wysokim średnim przyrostem udziału energii odnawialnej w końcowym zużyciu energii elektrycznej $(10,4 \%)$ i wysokim średnim przyrostem udziału energii odnawialnej w końcowym zużyciu paliw transportowych $(463,5 \%)$.

Pozostałe obiekto-okresy weszły w skład grupy czwartej, dla której średni przyrost udziału energii odnawialnej w końcowym zużyciu paliw transportowych wyniósł tylko $24,3 \%$, zaś średni przyrost udziału energii odnawialnej w końcowym zużyciu energii w ciepłownictwie i chłodnictwie wyniósł 7,1\%, a w końcowym zużyciu energii elektrycznej 9,4\%.

\section{Wnioski}

W latach 2005-2013 we wszystkich krajach Unii Europejskiej zanotowano wzrost udziału energii odnawialnej w końcowym zużyciu energii. Zmniejsza się zróżnicowanie państw ze względu na ten udział, zmniejsza się również asymetria rozkładu, a uporządkowania krajów w kolejnych latach są niemal identyczne. Jeśli zachowane zostanie dotychczasowe średnie tempo zmian, tylko trzy kraje (Francja, Luksemburg i Holandia) nie osiągną zapisanych w Dyrektywie celów.

Podobna sytuacja występuje w sektorze energii elektrycznej oraz ciepłownictwa i chłodnictwa. Wszystkie kraje odnotowały w tych sektorach wzrost udziału energii ze źródeł odnawialnych. W badanym okresie zmalało zróżnicowanie przy jednoczesnym zmniejszaniu się asymetrii rozkładu. W sektorze paliw transportowych następowały największe zmiany w uporządkowaniach krajów w kolejnych latach.

Cele dotyczące poszczególnych sektorów w Polsce zapisane w Krajowym Planie Działania są możliwe do zrealizowania, jeśli zachowane zostanie dotychczasowe średniookresowe tempo zmian.

Analiza współzależności udziału energii odnawialnej w poszczególnych sektorach wskazała na silną korelację liniową pomiędzy wartościami udziału energii odnawialnej w przypadku energii elektrycznej oraz ciepłownictwa i chłodnictwa. Duże możliwości transferu paliw transportowych spowodowały, że występuje mniejsza korelacja pomiędzy udziałem energii odnawialnej w końcowym zużyciu energii ogółem a udziałem energii odnawialnej w końcowym zużyciu energii w tym sektorze.

Znaczne zróżnicowanie krajów dotyczące nie tylko udziału energii odnawialnej w końcowym zużyciu energii zarówno ogółem, jak i w poszczególnych sektorach, ale szczególnie dynamiki wskazuje na zasadność zróżnicowania 
celów dla poszczególnych państw. Aktualne propozycje Komisji Europejskiej dotyczące celów na 2030 r. budzą kontrowersje. W nowej wersji unijnej strategii energetyczno-klimatycznej na 2030 r. przygotowanej przez Komisję Europejską znalazł się zapis o udziale zielonej energii w unijnym miksie energetycznym na poziomie $30 \%$. Z jednej strony uważa się taki zapis za mało ambitny. Z drugiej jednak strony pojawiają się głosy, że brak wiążących celów dla poszczególnych krajów członkowskich może doprowadzić do sytuacji, w której tylko wybrane kraje przeprowadzą transformację energetyczną i będą inwestować w nowe technologie, podczas gdy pozostałe kraje nie będą się czuły zobowiązane do realizacji europejskiego celu.

\section{Literatura}

Dyrektywa 2001/77/WE Parlamentu Europejskiego i Rady z dnia 27 września 2001 r. w sprawie wspierania produkcji na rynku wewnętrznym energii elektrycznej wytwarzanej ze źródeł odnawialnych, Dz.Urz. UE L 283, 27.10.2001.

Dyrektywa 2003/30/WE Parlamentu Europejskiego i Rady z dnia 8 maja 2003 r. w sprawie wspierania użycia $w$ transporcie biopaliw lub innych paliw odnawialnych, Dz.Urz. UE L 123, 17.05.2003.

Dyrektywa 2009/28/WE z dnia 23 kwietnia 2009 r. w sprawie promowania stosowania energii ze źródeł odnawialnych zmieniająca i w następstwie uchylająca dyrektywy 2001/77/WE oraz 2003/30/WE, Dz.Urz. UE L 140/16, 5.06.2009.

EU Energy in Figures. Statistical Pocketbook 2014 [2014], European Commission, Office of the European Union, Luxembourg.

Kaufmann L., Rousseeuw P.J. [1990], Finding Groups in Data: An Introduction to Cluster Analysis, Wiley, New York.

Kendall M.G. [1955], Rank Correlation Methods, Hafner Publishing, New York.

R: A Language and Environment for Statistical Computing [2015], $\mathrm{R}$ Core Team, R Foundation for Statistical Computing, Vienna, https://www.R-project.org/ (dostęp: 2.05.2015).

Uzupełnienie do Krajowego Planu Działania w zakresie energii ze źródeł odnawialnych z dnia 2 grudnia 2011 r., www.mg.gov.pl/energetyka/odnawialne+zrodla+energii/ krajowy+plan+dzialan (dostęp: 2.05.2015).

Walesiak M. [2011], Uogólniona miara odległości GDM w statystycznej analizie wielowymiarowej z wykorzystaniem programu $R$, Wydawnictwo Uniwersytetu Ekonomicznego we Wrocławiu, Wrocław.

Zervos A., Lins Ch., Tesnière L. [2011], Mapping Renewable Energy Pathways Towards 2020, European Renewable Energy Council, Brussels. 


\section{Spatio-temporal Analysis of the Dynamics of the Share of Renewable Energy in Gross Final Energy Consumption in the European Union} (Abstract)

The development of the renewable energy sector is one of the top priorities for the Polish government. In accordance with Directive 2009/28/EC, EU member states should increase their energy from renewable sources as a share of total energy consumption. The specific objective for Polish energy policy is to grow energy from renewable sources to comprise $15.5 \%$ of total energy production in 2020 (19.3\% for the electricity sector, $17 \%$ for the heating and cooling sector, and $10.2 \%$ for the transport fuels sector).

The main objective of this research is to assess the dynamics of the share of energy from renewable sources in particular sectors, including the electricity, heating, cooling and transport fuels sectors. The article ranks countries according to their share of energy from renewable sources in production and to the gross domestic product. It then compared the linear orderings. The purpose of this analysis is to test the hypothesis that the rank of EU countries in terms of their share of renewable energy in overall energy consumption did not change significantly in the years 2005-2013. Finally, it presents the results of the analysis of the relationship between the share of renewable energy in individual sectors. The countries are grouped according to their share of renewable energy in individual sectors.

Keywords: renewable energy, analysis of dynamics, linear ordering, classification. 